\title{
Taurine and the renal system
}

\author{
Russell W Chesney*, Xiaobin Han, Andrea B Patters \\ From $17^{\text {th }}$ International Meeting of Taurine \\ Fort Lauderdale, FL, USA. 14-19 December 2009
}

\begin{abstract}
Taurine participates in a number of different physiologic and biologic processes in the kidney, often reflected by urinary excretion patterns. The kidney is key to aspects of taurine body pool size and homeostasis. This review will examine the renal-taurine interactions relative to ion reabsorption; renal blood flow and renal vascular endothelial function; antioxidant properties, especially in the glomerulus; and the role of taurine in ischemia and reperfusion injury. In addition, taurine plays a role in the renal cell cycle and apoptosis, and functions as an osmolyte during the stress response. The role of the kidney in adaptation to variations in dietary taurine intake and the regulation of taurine body pool size are described. Finally, the protective function of taurine against several kidney diseases is reviewed.
\end{abstract}

\section{Introduction}

The interactions between the kidney and taurine are many and varied. Taurine participates in several biologic processes in the kidney, and the kidney influences specific aspects of taurine homeostasis [1]. The numerous physiologic regulators of taurine handling by the kidney have been recently reviewed [2]. Thus, this review will focus on several aspects of renal function in relation to taurine and will cover large biologic themes. In addition, the role of taurine in the pathophysiology of kidney disease will be examined.

The physiochemical properties of the $B$-amino acid taurine are probably responsible for some of its biologic characteristics. It is readily soluble in aqueous solutions. Taurine is not incorporated into protein, and can serve as an intracellular osmolyte. The taurine molecule acts as a zwitterion at physiologic $\mathrm{pH}$ and resides within the cell in millimolar quantities. Its accumulation within the cell requires active transport from the extracellular environment, where it is found in only micromolar quantities [3]. It has the lowest $\mathrm{pK}_{1}$ and $\mathrm{pK}_{2}$ of all amino acids. Some of these properties lead to the role of conjugation of bile acids [4] and uridine in tRNA [5].

\footnotetext{
* Correspondence: rchesney@uthsc.edu

Department of Pediatrics, University of Tennessee Health Science Center, and the Children's Foundation Research Center at Le Bonheur Children's Medical Center, 50 N. Dunlap, Memphis, Tennessee, 38103, USA Full list of author information is available at the end of the article
}

\section{Ion reabsorption}

The active uphill transport of taurine occurs via a sodiumdependent transporter (TauT) [6]. In addition to sodium, taurine uptake by renal epithelia requires chloride or bromide [7]. The model that best describes this transport is 2 $\mathrm{Na}^{+}: 1$ taurine: $1 \mathrm{Cl}^{-}$(Figure 1). Sodium and chloride move into cells by means of an external to internal downhill $\mathrm{Na}^{+}$ gradient (a chemical gradient), and then the sodium is pumped out of the cell by $\mathrm{Na}^{+} \mathrm{K}^{+}$-dependent ATPase. Taurine transport is stereospecific, inhibited by other B-amino acids and GABA (gamma-aminobutyric acid) but not by $\alpha$-amino acids, and is membrane surface-specific. In a proximal tubule cell line (LLC-PK1), uptake is maximal on the apical surface; in a distal tubule cell line (MDCK), uptake occurs at the basolateral surface (Figure 2) [8].

Taurine efflux from renal cells is dependent on the intracellular taurine concentration and requires the presence of both $\mathrm{Na}^{+}$and $\mathrm{Cl}^{-}$in the system. It does not contribute to the renal adaptive response described below. Efflux is much slower than uptake and has a higher $\mathrm{K}_{\mathrm{m}}$. That taurine egress is dependent on specific ions suggests that it is not purely passive diffusion, but probably involves a carrier-facilitated process [9].

Taurine and its transporter also interact with glucose. Taurine in the glomerular ultrafiltrate appears to blunt the rate of $\mathrm{Na}^{+}$-dependent uptake of glucose by renal tubules and can potentially lead to glucosuria. While it 


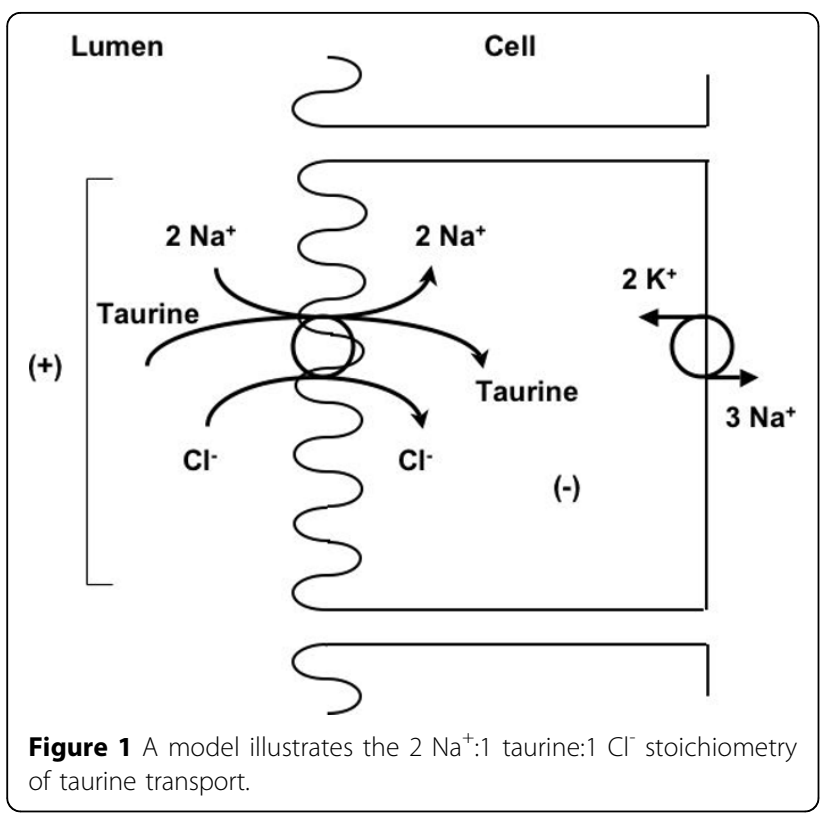

is tempting to assume that taurine molecules in the tubular lumen compete for sodium and hence reduce glucose uptake, the much higher concentration of glucose $(5.0 \mathrm{mM})$ makes this unlikely. Inhibition of the $\mathrm{Na}^{+}$-independent glucose transporter 1 (GLUT1) in activated macrophages (RAW264.7 cells) by taurine chloramine represents one mechanism by which inflammatory cell function can be modulated [10]. Some form of allosteric competition between taurine and GLUT1 may be relevant, but GLUT1 is commonly inhibited by vitamin $\mathrm{C}$ [11] rather than by amino acids. Also, because taurine is known to enhance insulin secretion [12], it may indirectly enhance glucose entry into cells. Hence, taurine may influence the intracellular as well as the transcellular movement of glucose.

\section{Urine}

\section{LLC-PK1 cells}

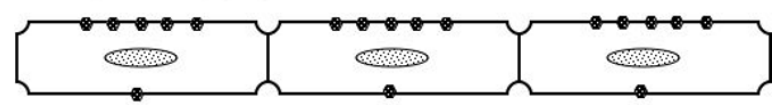

\section{MDCK cells}

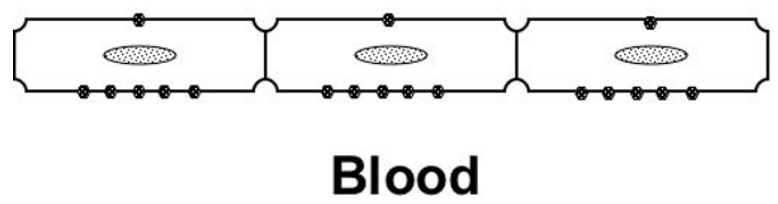

Figure $\mathbf{2}$ Taurine transport is membrane surface-specific.

\section{Renal blood flow}

Taurine has several effects on renal blood flow and endothelial cell function. Sato et al. used the deoxycorticosterone acetate (DOCA)-salt rat model to study the various vasoconstrictive and vasodilatory properties of taurine [13]. Taurine status in the rat can influence renal vascular resistance [14-16], autonomic nervous control of arterial blood pressure $[17,18]$ and the renal response to high sugar intake-induced baroreceptor reflex dysfunction [19]. Prenatal taurine exposure has long-term effects on arterial blood pressure and renal function in adult life.

Using the L-nitro-arginine methyl ester (L-NAME) hypertension model in the rat, $\mathrm{Hu}$ et al. have shown that taurine supplementation leads to increased serum levels of nitric oxide (NO) and $\mathrm{NO}$ synthase activity [14]. In addition, there is reduced renin-angiotensinaldosterone axis activity and blunted elevation of cytokine and endothelin levels [14]. Taurine administration also ameliorates hypertension in hypertension-prone Kyoto rats [17].

Under certain circumstances, taurine depletion in fetal or perinatal rats results in higher blood pressure in adulthood [15,18-20]. Because of renal immaturity, and the extremely high fractional excretion of taurine, much of the taurine administered to rat pups is excreted in the urine [21]. Hypothetically, this taurinuria could result in volume depletion with a chronic up-regulation of the renin-angiotensin system (RAS) [22]. Whether this leads to imprinting and overactivity of the RAS is unclear.

Taurine has been examined as a renoprotective agent in several rat models [23-26]. The amino acid has been shown to be renoprotective in both healthy and diseased rats on salt- and fat-supplemented diets. If treated with enalapril (to block the RAS) or taurine, both hypertensive and glucose-intolerant rats will manifest a significant reduction in urinary protein excretion. In addition, rats fed high salt or high fat diets will excrete more taurine, as do rats fed a high glucose diet. This taurinuria may relate to competition for either sodiumdependent transport processes, energy, or both.

\section{Antioxidant properties}

There exists extensive information regarding the antioxidant properties of taurine and its derivatives [27-30]. For this review, we will focus on studies relevant to the renal system.

Trachtman et al. showed that culturing renal mesangial cells in the presence of high glucose concentration resulted in build-up of advanced glycosylation products that could limit cell growth. Addition of the antioxidants taurine and vitamin $E$ reversed the growth inhibition [29]. 
The major mechanism of antioxidation is the reaction of taurine with hypochlorous acid $(\mathrm{HOCl})$ to form taurine chloramine. In several models of glomerular disease involving macrophage invasion there is increased intracellular activity of myeloperoxidase to yield $\mathrm{HOCl}$ arising from $\mathrm{H}_{2} \mathrm{O}_{2}$ present in renal tissue. These reactive oxygen species (ROS) can lead to DNA oxidation, protein nitration, and lipid peroxidation of renal cells $[27,28,30]$. Furthermore, oxidants arising from puromycin- or adriamycin-induced renal injury in rats are diminished following administration of $1 \%$ taurine in the drinking water [29]. Taurine has also been associated with reduction in oxidant levels in diabetic nephropathy [31].

\section{Ischemia/reperfusion injury}

A model of renal injury that involves antioxidant injury in the renal vessels is the renal ischemia/reperfusion model. When rat kidney undergoes $60 \mathrm{~min}$ of ischemia followed by 90 min reperfusion, there is a substantial rise in serum creatinine and fall in renal ATP content. Prior intravenous administration of taurine at $40 \mathrm{mg} / \mathrm{kg}$ significantly reduces injury, as reflected by final serum creatinine levels much lower than in control rats that did not receive taurine [32]. No protection in terms of ATP content was found. In a saphenous vein model, ischemia reperfusion significantly reduced endothelial cell survival by increasing both apoptosis and necrosis [33]. These changes were accompanied by higher intracellular ROS and calcium ions and a reduction in endothelial nitric oxide synthase expression. Administration of taurine either prior to or following ischemia also attenuated epithelial cell apoptosis and necrosis.

The addition of taurine to University of Wisconsin (UW) solution was able to reduce tissue alterations during hypoxia and reoxygenation and permitted recovery of energy metabolism in LLC-PK1 cells [34]. However, it is in hepatic tissue that taurine supplementation of UW solution is more dramatic in tissue preservation [32,34,35].

The most important role for taurine in oxidant injury is probably the local and systemic scavenging of ROS. Taurine chloramine has been shown to serve as an oxidant reservoir, exhibiting delayed oxidant effects or acting at a distant site [36]. This phenomenon is particularly noteworthy in phagocytes, which are a source of taurine-related antioxidants [37] and are prevalent in an early phase of inflammation in the glomerulus and tubules [29].

\section{Cell cycle and apoptosis}

Evidence has emerged that taurine and its transporter, the TauT protein, are important in the regulation of the cell cycle and apoptosis of kidney cells [38]. Taurine accumulates within the cells via active transport by TauT, and, hence, the quantity of transporter protein in the cell membrane determines intracellular $\beta$-amino acid concentration [1]. Cisplatin, a nephrotoxic chemotherapeutic agent, reduces taurine accumulation in renal cells through a p53-dependent process in LLCPK1 cells [38]. In human embryonic kidney cells (293 cells), cisplatin up-regulates the proto-oncogene c-Jun. These variable responses to the anti-tumor agent can be shown by reporter assay and analysis, DNA binding, and Western blots of taurine transporter protein in cells. The functional TauT gene plays a modifying role in cisplatin-induced renal injury, and the transcription rate for TauT is regulated by p53 and c-Jun. The balance of such regulation determines the rate of synthesis of TauT protein, and thereby influences the fate of renal cells.

The cell cycle-relevant pathway involving gene expression of cyclin-c and the TauT gene is cooperatively regulated by renal cells in response to hypertonicity [39] and reduced TauT promoter activity by doxorubicin-induced activation of p53. This p53 activation can be seen in human fetal kidney cells (293) and porcine proximal tubule cells (LLC-PK1), but in a cell line devoid of p53 expression, [10](1) cells, there is no repression of promoter [38]. With truncation of the TauT promoter or with mutation of the p53 binding site there is no repression of TauT activity. Activation of the WT1 (Wilms tumor 1 gene) binding site in the promoter region up-regulates TauT, as does c-Jun. Figure 3 depicts the promoter region of TauT (3a) and the details of the intracellular signaling that regulate the gene $(3 \mathrm{~b})$. Among the binding sites in the promoter region is a taurine response element (TREE) as well as the proto-oncogenes previously mentioned $[1,2,38]$.

The product of TauT expression is TauT, a transporter protein containing 12 membrane-spanning domains inserted into the apical or basolateral membranes of renal cells. The taurine transporter has been cloned from several species and tissues, including rat brain [6] and dog kidney [40]. The genes encoding TauT in various species share a high degree of homology, residing on chromosome 6 in the mouse and 3p21-25 in man [41]. A renal adaptive response to taurine availability has been demonstrated in many mammalian species, including humans [42]. The mechanisms for this adaptive response, described in detail below, occur at the levels of transcription, translation, and post-translational modification [2]. Phosphorylation of serine 322 by protein kinase $\mathrm{C}$ (PKC) results in reduced transporter activity. This phosphorylation site is on the fourth intracellular loop $\left(\mathrm{S}_{4}\right)$, a highly conserved motif in all mammalian species examined $[6,40]$. 


\section{a}

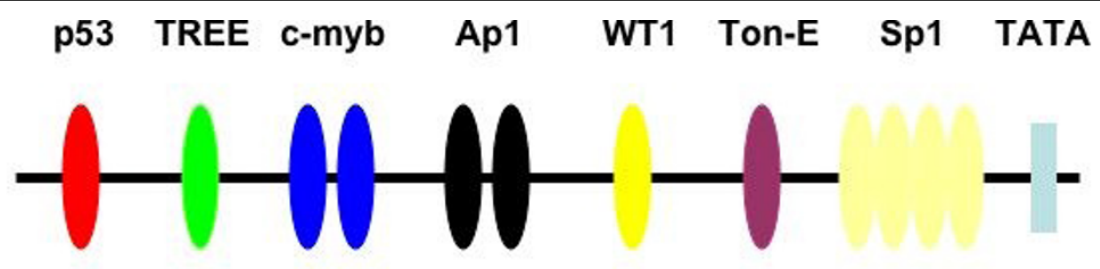

b

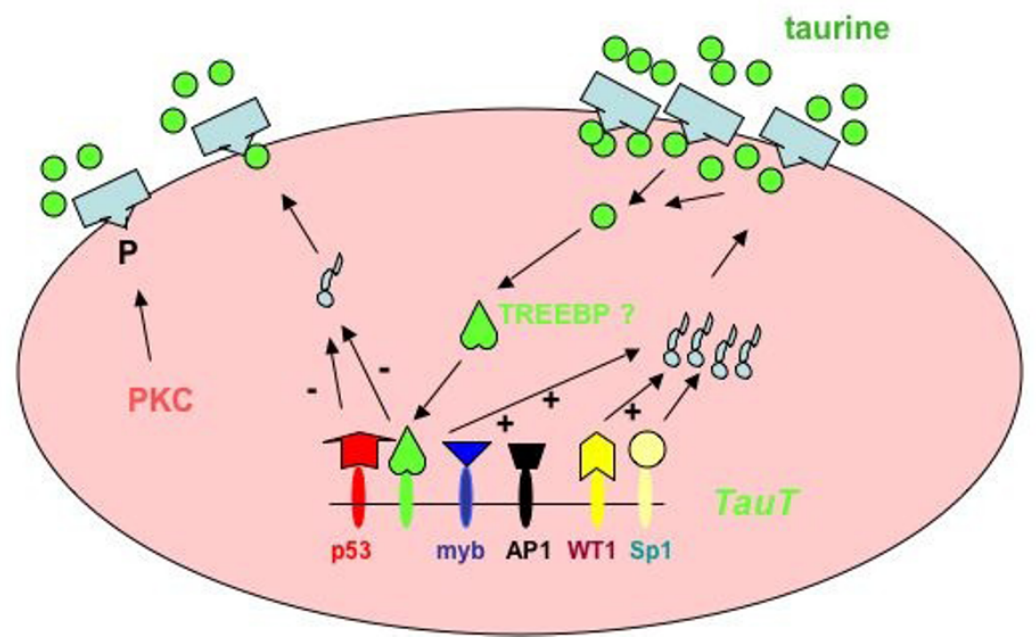

Figure 3 (a) The promoter region of TauT contains important binding sites. (b) Details of the intracellular signaling that regulate the gene.

\section{Stress response and taurine as a renal osmolyte}

Sorbitol, myo-inositol, betaine, $\alpha$-glycerophosphorylcholine and taurine have been identified as major osmolytes in the renal medulla [43-45]. The taurine uptake process responds to osmolar signals under three special circumstances: 1) In fish adapting from fresh water to sea water or vice versa $[42,46,47]$; 2) In the mammalian brain under conditions of hyper- or hyponatremia $[48,49]$; 3) In the unique osmolar environment of the renal medulla [43-45,50]. Osmolar regulation results in movement of taurine into or out of the medullary cell rather than transcellular movement (reabsorption) (Figure 4). The renal medulla is the site of urinary concentration or dilution, the countercurrent multiplier mechanism, and aquaporin activity to form water channels. It can establish an osmolar gradient of 50 to 1200 mOsm in man, and even steeper gradients in rodents [51]. Osmoregulation of taurine transport occurs in cells of the loop of Henle and the medullary collecting duct. The relevant biologic process is termed "cell volume regulation" [44,45,52], (Figure 4). Several studies have demonstrated that medullary cells in culture (MDCK or M1 cells) exhibit taurine transport across the basolateral surface rather than the apical surface $[44,45,50]$. A response to hyperosmolarity is not evident in proximal cell lines [50].
Handler and Kwon have shown that cells that respond to hyperosmolar stress have a tonicity response element (TonE) that responds to a TonE binding protein (TonEBP) [44,53]. Extracellular sucrose or raffinose leads to increased binding of TonEBP to TonE, up-regulation of the genes for osmolar transporters (sorbitol, myoinositol, etc.), increased production of mRNA for TauT protein synthesis, export and insertion of protein into the basolateral cell membrane, and enhanced transport of taurine into the cell (Figure 5a) [44,50]. Ito et al. have recently shown that the TonE site is located on the promoter region proximal to -124 and distal to -99 (Figure 5b) [53]. A mutant TonE was unresponsive to hypertonicity. This study also demonstrates how the TonE/TonEBP system regulates cell volume and prevents hyperosmolar stress [53].

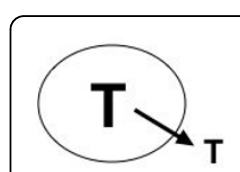

Hypotonic

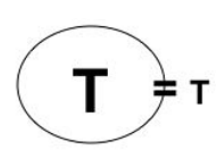

Isotonic

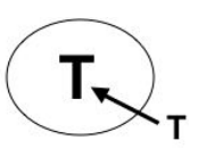

Hypertonic
Figure 4 Taurine's role as an osmolyte is shown by its net movement under different conditions of tonicity. 


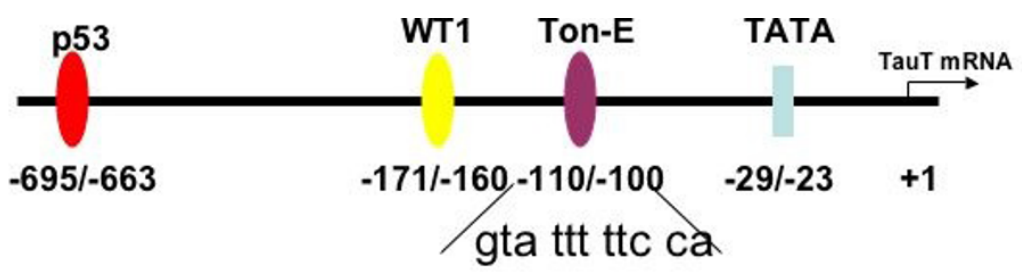

b

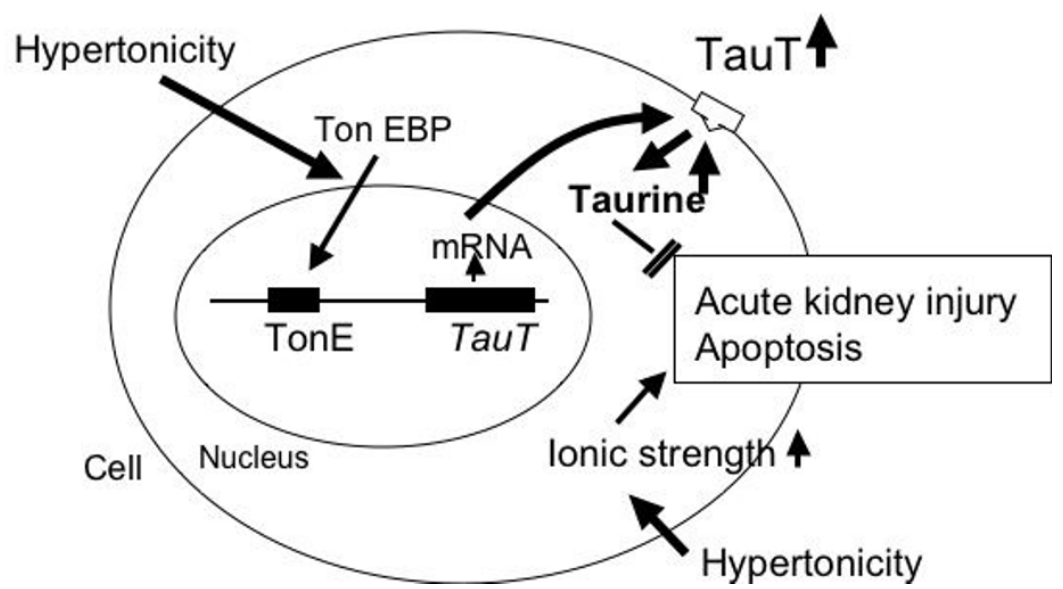

Figure 5 (a) Location of the TonE site on the TauT gene promoter region; (b) Model of TonE and TauT gene activity following exposure to hypertonic conditions.

Renal regulation of taurine body pool size

Humans and other mammals on diets of differing taurine or sulfur amino acid content excrete different amounts of taurine, particularly as a percent of the filtered load [2]. This is unusual because amino acid reabsorption by the kidney is highly efficient and generally exceeds 99\%. Urinary taurine excretion is low when dietary taurine is restricted, as in a vegetarian diet. Conversely, when taurine intake is high, as in a diet rich in meat and seafood, taurine excretion is high. Han et al. review many of the specifics of this phenomenon [2].

Although renal regulation of ion reabsorption is a long-recognized concept in transport physiology, application of this principle to an amino acid is recent. Examined in terms of the fractional excretion of taurine, a variation of $0.5 \%$ to $80 \%$ has been found [54]. From a renal physiologic viewpoint, both an increase and reduction of urinary excretion suggest an adaptive regulation of transport, as is observed for the phosphate ion. We use the term "renal adaptive response to alterations in taurine intake" to describe these observations. Adaptation of the taurine transporter system is a limited phenomenon exhibited by the kidney and the gut, and under conditions of malnutrition [2]. From a nutritional perspective, all mammals should retain amino acids. However, because taurine is a $\beta$-amino acid and is devoid of a carboxyl group, it cannot be incorporated into protein and resides freely in intracellular water. Among other features is that taurine is not metabolized by eukaryotes and does not contribute to gluconeogenesis, but it does participate in conjugation of certain compounds (such as bile acids). It is largely inert and not a source of energy. These ideal physiochemical properties of taurine lead to a central hypothesis that taurine can be responsible for cell volume regulation, because taurine movement across the membrane surface of a cell "can evoke changes in the concentration of solutes and solvents within a cell" [52].

If taurine movement is important in the maintenance of cell volume, what regulates the transport from a dietary perspective? The transport of taurine in vivo appears to be precisely regulated by the kidney, and is mimicked in vitro in a variety of renal systems, including uptake into renal slices, renal cells in culture, isolated renal tubules, and isolated brush border membrane vesicles. It is regulated at both the level of mRNA transcription and protein synthesis [2].

The renal adaptive response was first described in rats fed a low taurine diet (LTD, containing suboptimal concentration of the precursor methionine), a normal taurine diet (NTD), or a diet supplemented with $3 \%$ (high) taurine (HTD) [54]. Specific taurine transporter 
mRNA levels are higher in LTD-fed rats and lower in HTD-fed rats as compared to NTD-fed rats. Western blot analysis shows more taurine transporter protein in membranes from LTD-fed animals and less in those fed HTD. The transcription rate is higher in cells in culture deprived of taurine, and lower in cells exposed to excess taurine [55-57]. Exposure of cells to $\beta$-alanine, which depletes intracellular taurine, leads to enhanced uptake. Likewise, in vivo, fasted rats show higher taurine reabsorption rates and increased uptake by brush border membrane vesicles [58]. Renal brush border membrane vesicles prepared from kidneys of taurine-deprived felines, who require dietary taurine to maintain usual tissue levels, show greatly enhanced taurine uptake [59]. This evidence indicates that whatever reduces intracellular taurine content up-regulates the TauT gene and synthesis of TauT protein. Likewise, with increased taurine availability, increased dietary intake and increased intracellular taurine concentration, the uptake of taurine by vesicles and cells is reduced and the process is down-regulated.

In an effort to clarify the signal for the up- or downregulation, truncation analysis of the promoter region revealed that the taurine response element (TREE) resides between the c-myb and p53 binding sites (Figure 3a). Truncation proximal to this site blocks the adaptive response, as shown by reporter assay [2]. The molecule that TREE responds to is not established, but it is possible that it is the intracellular concentration of the taurine molecule per se.

Plasma taurine levels do not vary greatly with the availability of dietary taurine. Using specific antibodies, taurine can be found in the nucleus, and thus is present at the site of transcription. Addition of taurine to cell cultures that have adapted to a low taurine environment can rapidly (within $8 \mathrm{hr}$ ) reverse the up-regulation response [8]. Both the rapid and the slower classic adaptive responses are found in numerous mammalian species, including man, dog, pig and rodent. It is evident in herbivores, carnivores and omnivores [2]. Depending on taurine intake, the urinary fractional excretion of taurine can vary from $0.5 \%$ to $80.0 \%$ (Figure 6 ).

The role of taurine in the pathophysiology of the kidney Taurine has been shown to play a role in four different forms of kidney disease: glomerulonephritis, diabetic nephropathy, chronic renal failure, and acute kidney injury (AKI). Much of the work on the role of taurine in relation to kidney disease has been performed in animal models, especially murine species. Many studies were performed nearly two decades ago and are descriptive, with the exception of the studies involving taurine chloramine. Only in the area of protection of the kidney against AKI have intracellular and molecular mechanisms been explored with the use of transgenic and knockout mouse models and knockdown cell lines.

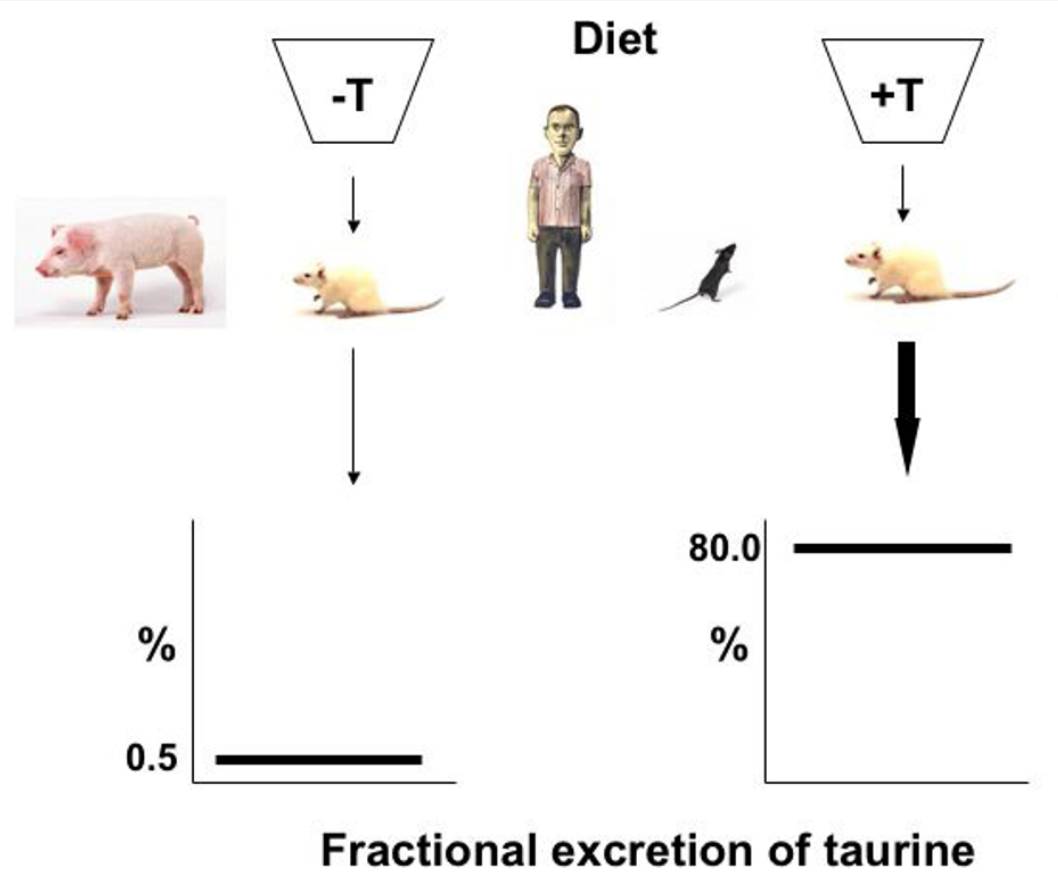

Figure 6 The renal adaptive response to dietary taurine intake conserves the total taurine body pool by reabsorbing or excreting taurine depending on its availability. 


\section{Protection against glomerulonephritis}

Trachtman has reviewed the evidence that taurine functions as a protective agent against immune- or toxicityinduced forms of glomerulonephritis [29]. In the Masugi glomerulonephritis model, rat kidney homogenates are injected into rabbits. After several weeks, rabbit serum is injected into rats. There occurs a heterologous phase in which injected antibodies lead to the migration of neutrophils into rat glomeruli. Myeloperoxidase (MPO) located in neutrophils causes generation of radicals, including hypochlorous acid [28,30,60,61]. Hypochlorous acid activates tyrosine phosphorylation signal pathways, leading to calcium signaling and tumor necrosis factor $\alpha$ (TNFa) production [61]. In $\mathrm{MPO}^{-1-}$ mice, fewer reactants are generated [60].

Subsequently, in an autologous phase, T cells and macrophages invade. The addition of taurine chloramine to the diet appears to inhibit the function of antigenpresenting cells and $\mathrm{T}$ cells in $\mathrm{T}$ cell-induced crescentic glomerulonephritis [60]. Lian et al. showed that taurine in drinking water reduced urinary protein excretion, and both serum and urine platelet-activating factor (PAF) levels [62]. Renal cortex and medulla PAF values are also lower than in control rats.

Another component of glomerulonephritis is an increase in glomerular albumin permeability (GAP). In a model using isolated rat glomeruli, which are infiltrated by neutrophils, $\mathrm{H}_{2} \mathrm{O}_{2}$ alone does not increase GAP, but $\mathrm{H}_{2} \mathrm{O}_{2}$ and MPO together do increase GAP [63]. This increase can be inhibited by superoxide dismutase, catalase or taurine.

A model of chronic puromycin aminonucleoside nephropathy that resembles human focal segmental glomerulosclerosis (FSGS) can be induced in rats. When rats are given $1 \%(\mathrm{w} / \mathrm{v})$ taurine in their drinking water, urinary albumin excretion, segmental glomerulosclerosis and tubulointerstitial injury are significantly diminished. The urine albumin/creatinine ratio is lower in taurinesupplemented animals, as are levels of the oxidant malondialdehyde in renal cortex. While the presumed mechanism of nephroprotection is the formation of taurine chloramine from taurine, this was not directly measured [64].

\section{Protection against diabetic nephropathy}

Taurine has afforded renal protection against models of diabetic nephropathy [31]. The importance of this observation relates to the fact that diabetes mellitus (type 1 and type 2) is the predominant cause of end stage renal disease and the need for dialysis in North America [65]. In rats with streptozocin-induced diabetic nephropathy, addition of taurine to the drinking water and exogenous insulin inhibited the increase in glomerular planar area and ameliorated the condition, as did vitamin E [31]. Administration of vitamin E and taurine is associated with a reduction in advanced glycosylation end products and the extent of lipid peroxidation. Taurine can also neutralize the aldehydes of glycation end products. The formation of Schiff's base between taurine and the aldehydes may diminish glucose toxicity. Taurine and its congeners reduce the formation of intracellular oxidants and afford protection against erythrocyte membrane damage [66], which could also reduce the fragility of erythrocytes within glomerular capillaries.

Another hypothesis concerning the importance of taurine in diabetic nephropathy involves the increased production of sorbitol. Simply stated, the elevated extracellular concentration of glucose disturbs cellular osmoregulation and sorbitol is synthesized intracellularly via the polyol pathway [67]. Intracellular accumulation of sorbitol crowds out other intracellular osmolytes, including taurine and myo-inositol. This disturbance of cell volume regulation might be altered by taurine supplementation, but this has not been tested [67].

\section{Protection against chronic renal failure}

In general, human patients with chronic renal failure have reduced plasma and muscle intracellular concentrations of taurine [68]. However, an open label, nonrandomized trial of taurine supplementation $(100 \mathrm{mg} /$ $\mathrm{kg} /$ day) in 10 hemodialysis patients resulted in extremely high taurine levels in plasma and muscle [69]. The plasma concentration rose from $50 \mu \mathrm{M}$ to $712-2481$ $\mu \mathrm{M}$ after 10 weeks of therapy, and muscle values more than doubled [69], likely because no renal adaptive response is possible in these patients and taurine cannot be excreted. Clearance by dialysis was not measured.

\section{Protection against acute kidney injury}

Several models of AKI have been used to examine the influence of taurine in this process. In a gentamicin toxicity model, rats are injected with the aminoglycoside antiobiotic, leading to a rise in serum creatinine and histologic features of acute tubular necrosis. Administration of taurine attenuated the rise in creatinine and there was less accumulation of gentamicin [70]. In this model, the content of glutathione peroxidase and superoxide dismutase are similar in kidneys of taurine-treated rats and controls.

Acute kidney injury is a major problem in patients with sepsis, toxic injury and shock. The overall mortality rate is approximately 50\% [71]. In cancer patients receiving chemotherapeutic agents, evidence of kidney injury, as defined by elevation of biomarkers, is common. Cisplatin is a frequently used chemotherapeutic agent, limited mainly by its nephrotoxicity. As many as $25 \%$ to $35 \%$ of patients experience a significant decline in renal function after a single dose of cisplatin [72]. 
Elevated expression of the tumor suppressor gene p53 has been detected in the kidneys of rats with cisplatininduced AKI [73]. Jiang et al. have shown that p53 is an early signal in cisplatin-induced apoptosis in renal tubular cells [74]. These findings suggest that altered expression of distinct p53 target genes may be responsible for p53-induced progressive renal failure.

Our studies have shown that TauT is negatively regulated by p53 in renal cells [75]. Cisplatin, which stimulates p53 production, accumulates in all cell types of the nephron but is preferentially taken up by highly susceptible cells in the S3 segment of the proximal tubule [76], which is also the site where adaptive regulation of TauT occurs [77]. Cisplatin has been shown to impair the function of the taurine transporter and to down-regulate expression of TauT at the transcriptional level in a dose-dependent fashion [78]. We hypothesized that TauT plays a role as an anti-apoptotic gene and functions to protect renal cells from cisplatin-induced nephrotoxicity in vivo.

Transgenic mice over-expressing human TauT and wild-type mice were injected with cisplatin or saline; renal failure biomarkers (blood urea nitrogen, creatinine, urinary protein excretion) were measured and the mortality rate recorded [78]. Over-expression of TauT in the transgenic mice conferred significant protection against renal damage and death caused by cisplatin as compared to drug-treated control animals. Histological analysis of kidneys from cisplatin-treated transgenic mice showed greater amounts of membrane-bound TauT protein, higher levels of intracellular taurine, and less necrosis and apoptosis than the kidneys of cisplatin-treated control mice. The histological findings were similar to those found in saline-injected control animals [38].

\section{Physiologic roles for taurine relative to the kidney}

It is possible to develop a structural-functional map of the kidney based upon information presented in this review. The nephron, the basic unit of the kidney, has several different cell types that behave in a variety of ways when interacting with taurine. The major characteristics of taurine in terms of kidney function are shown in Table 1. Although many of these roles may overlap in different renal tissue types, the function of each structural part sets the paradigm within which taurine will operate.

The effect of taurine on renal blood vessels is to alter blood flow, and probably to stabilize the endothelium of the extensive renal vascular network [33]. Taurine influences blood flow within all types of vessels (capillaries, venules and arterioles) through several mechanisms discussed previously, such as NO synthase activity, the rheology of erythrocytes, the renin-angiotensin system
Table 1 The role of taurine in various renal structures

\begin{tabular}{ll}
\hline Renal Structure & Role of Taurine \\
\hline Vasculature & Regulate blood flow \\
Glomerulus & Scavenge ROS (reactive oxygen species) \\
Proximal tubule & $\mathrm{Na}^{+}$transport \\
& Regulate taurine body pool size \\
Medulla & Osmoregulation \\
& Cell volume regulation \\
\hline
\end{tabular}

activity and vascular tone $[15,16,24]$. In the glomerulus, where inflammatory cytokines evoke leukocyte migration, $\mathrm{T}$ cell activation, fibrosis, sclerosis and scarring, the value of taurine as an antioxidant is paramount. Taurine scavenges ROS that can influence podocyte function and increase protein excretion. In the proximal tubule, the site of bulk reabsorption of ions, organic solutes and water, taurine influences sodium transport and is taken up itself to maintain the body pool size in an adaptive response to variations in dietary availability. The taurine transporter system maintains the steep plasma (extracellular, $\mu \mathrm{M})$ to intracellular $(\mathrm{mM})$ concentration gradient despite huge variations in taurine intake. In the medulla, taurine is critical to cell volume regulation, moving into or out of collecting duct cells relative to external osmolarity. Taurine's role as an osmolyte is likely important in many cell types in nearly all organs, but it is especially evident in renal medullary cells, where final urine concentration is established.

\section{Abbreviations}

AKI: acute kidney injury; DOCA: deoxycorticosterone acetate; FSGS: focal segmental glomerulosclerosis; GABA: gamma-aminobutyric acid; GAP: glomerular albumin permeability; GLUT1: glucose transporter 1; $\mathrm{HOCl}$ : hypochlorous acid; HTD: high taurine diet; L-NAME: L-nitro-arginine methyl ester; LTD: low taurine diet; MPO: myeloperoxidase; NO: nitric oxide; NTD: normal taurine diet; PKC: protein kinase C; PAF: platelet-activating factor; RAS: renin-angiotensin system; ROS: reactive oxygen species; TonE: tonicity response element; TonEBP: TonE binding protein; TREE: taurine response element; TNF: tumor necrosis factor ; UW: University of Wisconsin.

\section{Acknowledgements}

This article has been published as part as part of Journal of Biomedical Science Volume 17 Supplement 1, 2010: Proceedings of the 17th International Meeting of Taurine. The full contents of the supplement are available online at http://www.jbiomedsci.com/supplements/17/S1.

\section{Competing interests}

The authors declare that they have no competing interests.

Published: 24 August 2010

\section{References}

1. Han X, Budreau AM, Chesney RW: The taurine transporter gene and its role in renal development. Amino Acids 2000, 19(3-4):499-507.

2. Han X, Patters AB, Jones DP, Zelikovic I, Chesney RW: The taurine transporter: mechanisms of regulation. Acta Physiol (Oxf) 2006, 187(12):61-73.

3. Chesney RW, Scriver CR, Mohyuddin F: Localization of the membrane defect in transepithelial transport of taurine by parallel studies in vivo and in vitro in hypertaurinuric mice. J Clin Invest 1976, 57(1):183-193. 
4. Hoffman NE, Iser JH, Smallwood RA: Hepatic bile acid transport: effect of conjugation and position of hydroxyl groups. Am J Physiol 1975, 229(2):298-302.

5. Schaffer $S W$, Jong $C J, K C R$, Azuma J: Physiological roles of taurine in heart and muscle. J Biomed Sci 2010, 17(Suppl 1):S2

6. Smith KE, Borden LA, Wang CH, Hartig PR, Branchek TA, Weinshank RL: Cloning and expression of a high affinity taurine transporter from rat brain. Mol Pharmacol 1992, 42(4):563-569.

7. Zelikovic I, Stejskal-Lorenz E, Lohstroh P, Budreau A, Chesney RW: Anion dependence of taurine transport by rat renal brush-border membrane vesicles. Am J Physiol 1989, 256(4 Pt 2):F646-655.

8. Jones DP, Miller LA, Chesney RW: Adaptive regulation of taurine transport in two continuous renal epithelial cell lines. Kidney Int 1990, 38(2):219-226

9. Chesney RW, Budreau AM: Efflux of taurine from renal brush border membrane vesicles: is it adaptively regulated? Pediatr Nephrol 1993, 7(1):35-40

10. Thaeromor A, Wyss JM, Jirakulsomchok D, Roysummuti S: High sugar intake via the renin-angiotensin system blunts the baroreceptor reflec in adult rates that were perinatally depleted of taurine. J Biomed Sci 2010, 17(Suppl 1):S30

11. Sagun KC, Carcamo JM, Golde DW: Vitamin C enters mitochondria via facilitative glucose transporter 1 (Glut1) and confers mitochondrial protection against oxidative injury. Faseb J 2005, 19(12):1657-1667.

12. Nakaya Y, Minami A, Harada N, Sakamoto S, Niwa Y, Ohnaka M: Taurine improves insulin sensitivity in the Otsuka Long-Evans Tokushima Fatty rat, a model of spontaneous type 2 diabetes. Am J Clin Nutr 2000, 71(1):54-58

13. Sato $Y$, Ogata E, Fujita T: Hypotensive action of taurine in DOCA-salt ratsinvolvement of sympathoadrenal inhibition and endogenous opiate. Jpn Circ J 1991, 55(5):500-508.

14. Hu J, Xu X, Yang J, Wu G, Sun C, Lv Q: Antihypertensive effect of taurine in rat. Adv Exp Med Biol 2009, 643:75-84.

15. Roysommuti S, Lerdweeraphon W, Malila P, Jirakulsomchok D, Wyss JM: Perinatal taurine alters arterial pressure control and renal function in adult offspring. Adv Exp Med Biol 2009, 643:145-156.

16. Satoh $\mathrm{H}$, Kang J: Modulation by taurine of human arterial stiffness and wave reflection. Adv Exp Med Biol 2009, 643:47-55.

17. Nara Y, Yamori Y, Lovenberg W: Effect of dietary taurine on blood pressure in spontaneously hypertensive rats. Biochem Pharmacol 1978, 27(23):2689-2692.

18. Roysommuti S, Suwanich A, Jirakulsomchok D, Wyss JM: Perinatal taurine depletion increases susceptibility to adult sugar-induced hypertension in rats. Adv Exp Med Biol 2009, 643:123-133.

19. Thaeomor A, Jirakulsomchok D, Roysommuti S: High sugar intake blunts baroreceptor reflex in perinatal taurine-depleted female rats via the renin-angiotensin system. Adv Exp Med Biol, 2010

20. Roysommuti S, Suwanich A, Lerdweeraphon W, Thaeomor A, Jirakulsomchok D, Wyss JM: Sex dependent effects of perinatal taurine exposure on the arterial pressure control in adult offspring. Adv Exp Med Biol 2009, 643:135-144.

21. Friedman AL, Jax DK, Chesney RW: Developmental aspects of renal betaamino acid transport. III. Ontogeny of transport in isolated renal tubule segments. Pediatr Res 1981, 15(1):10-13.

22. Gomez RA, Tufro-McReddie A, Everett AD, Pentz ES: Ontogeny of renin and AT1 receptor in the rat. Pediatr Nephrol 1993, 7(5):635-638

23. Abebe W, Mozaffari MS: Taurine depletion alters vascular reactivity in rats. Can J Physiol Pharmacol 2003, 81(9):903-909.

24. Mozaffari MS, Miyata N, Schaffer SW: Effects of taurine and enalapril on kidney function of the hypertensive glucose-intolerant rat. $\mathrm{Am} J$ Hypertens 2003, 16(8):673-680.

25. Mozaffari MS, Patel C, Abdelsayed R, Schaffer SW: Accelerated NaClinduced hypertension in taurine-deficient rat: role of renal function. Kidney Int 2006, 70(2):329-337.

26. Mozaffari MS, Schaffer SW: Chronic taurine treatment ameliorates reduction in saline-induced diuresis and natriuresis. Kidney Int 2002, 61(5):1750-1759.

27. Kim C, Choi HS, Kim JW: Taurine chloramine inhibits the production of nitric oxide and superoxide anion by modulating specific mitogenactivated protein kinases. Adv Exp Med Biol 2006, 583:493-498.
28. Marcinkiewicz J, Kurnyta M, Biedron R, Bobek M, Kontny E, Maslinski W: Anti-inflammatory effects of taurine derivatives (taurine chloramine, taurine bromamine, and taurolidine) are mediated by different mechanisms. Adv Exp Med Biol 2006, 583:481-492.

29. Trachtman H, Futterweit S, Prenner J, Hanon S: Antioxidants reverse the antiproliferative effect of high glucose and advanced glycosylation end products in cultured rat mesangial cells. Biochem Biophys Res Commun 1994, 199(1):346-352.

30. Weiss SJ, Klein R, Slivka A, Wei M: Chlorination of taurine by human neutrophils. Evidence for hypochlorous acid generation. $J$ Clin Invest 1982, 70(3):598-607.

31. Trachtman H, Futterweit S, Maesaka J, Ma C, Valderrama E, Fuchs A, Tarectecan AA, Rao PS, Sturman JA, Boles TH: Taurine ameliorates chronic streptozocin-induced diabetic nephropathy in rats. Am J Physiol 1995, 269(3 Pt 2):F429-438.

32. Michalk DV, Hoffmann B, Minor T: Taurine reduces renal ischemia/ reperfusion injury in the rat. Adv Exp Med Biol 2003, 526:49-56.

33. Moloney MA, Casey RG, O'Donnell DH, Fitzgerald P. Thompson C, BouchierHayes DJ: Two weeks taurine supplementation reverses endothelial dysfunction in young male type 1 diabetics. Diab Vasc Dis Res 2010.

34. Wingenfeld P, Minor T, Gehrmann U, Strubind S, Isselhard W, Michalk D: Hypoxic cellular deterioration and its prevention by the amino acid taurine in a transplantation model with renal tubular cells (LLC-PK1). In Vitro Cell Dev Biol Anim 1995, 31(7):483-486.

35. Michalk DV, Wingenfeld P, Licht C, Ugur T, Siar LF: The mechanisms of taurine mediated protection against cell damage induced by hypoxia and reoxygenation. Adv Exp Med Biol 1996, 403:223-232.

36. Ogino T, Than TA, Hosako M, Ozaki M, Omori M, Okada S: Taurine chloramine: a possible oxidant reservoir. Adv Exp Med Biol 2009, 643:451-461.

37. Kim C, Cha YN: Production of reactive oxygen and nitrogen species in phagocytes is regulated by taurine chloramine. Adv Exp Med Biol 2009, 643:463-472.

38. Han X, Yue J, Chesney RW: Functional TauT protects against acute kidney injury. J Am Soc Nephrol 2009, 20(6):1323-1332.

39. Oh C, Choi YJ, Kim HG, Lee DH: Osmosensitive gene expression of taurine transporter and cyclin C in embryonic fibroblast cells. Adv Exp Med Biol 2006, 583:49-57.

40. Uchida S, Kwon HM, Yamauchi A, Preston AS, Marumo F, Handler JS: Molecular cloning of the cDNA for an MDCK cell $\mathrm{Na}(+)$ - and $\mathrm{Cl}$ (-)-dependent taurine transporter that is regulated by hypertonicity. Proc Natl Acad Sci U S A 1992, 89(17):8230-8234.

41. Patel A, Rochelle JM, Jones JM, Sumegi J, Uhl GR, Seldin MF, Meisler MH, Gregor P: Mapping of the taurine transporter gene to mouse chromosome 6 and to the short arm of human chromosome 3. Genomics 1995, 25(1):314-317.

42. Sturman JA: Taurine in development. J Nutr 1988, 118(10):1169-1176.

43. Burg MB, Ferraris JD, Dmitrieva NI: Cellular response to hyperosmotic stresses. Physiol Rev 2007, 87(4):1441-1474.

44. Handler JS, Kwon HM: Transcriptional regulation by changes in tonicity. Kidney Int 2001, 60(2):408-411.

45. Uchida S, Nakanishi T, Kwon HM, Preston AS, Handler JS: Taurine behaves as an osmolyte in Madin-Darby canine kidney cells. Protection by polarized, regulated transport of taurine. J Clin Invest 1991, 88(2):656-662.

46. Huxtable RJ: Physiological actions of taurine. Physiol Rev 1992, 72(1):101-163.

47. Schrock H, Forster RP, Goldstein L: Renal handling of taurine in marine fish. Am J Physiol 1982, 242(1):R64-69.

48. Chesney RW: The role of the kidney in protecting the brain against cerebral edema and neuronal cell swelling. J Pediatr 2008, 152(1):4-6.

49. Trachtman H, Barbour R, Sturman JA, Finberg L: Taurine and osmoregulation: taurine is a cerebral osmoprotective molecule in chronic hypernatremic dehydration. Pediatr Res 1988, 23(1):35-39.

50. Jones DP, Miller LA, Chesney RW: Polarity of taurine transport in cultured renal epithelial cell lines: LLC-PK1 and MDCK. Am J Physiol 1993, 265(1 Pt 2):F137-145.

51. Dantzler WH, Silbernagl S: Renal tubular reabsorption of taurine, gammaaminobutyric acid (GABA) and beta-alanine studied by continuous microperfusion. Pflugers Arch 1976, 367(2):123-128. 
52. Lambert IH: Regulation of the cellular content of the organic osmolyte taurine in mammalian cells. Neurochem Res 2004, 29(1):27-63.

53. Ito T, Fujio Y, Schaffer SW, Azuma J: Involvement of transcriptional factor TonEBP in the regulation of the taurine transporter in the cardiomyocyte. Adv Exp Med Biol 2009, 643:523-532.

54. Chesney RW, Gusowski N, Friedman AL: Renal adaptation to altered dietary sulfur amino acid intake occurs at luminal brushborder membrane. Kidney Int 1983, 24(5):588-594.

55. Han X, Budreau AM, Chesney RW: Functional expression of rat renal cortex taurine transporter in Xenopus laevis oocytes: adaptive regulation by dietary manipulation. Pediatr Res 1997, 41(5):624-631.

56. Han X, Budreau AM, Chesney RW: Adaptive regulation of MDCK cell taurine transporter (pNCT) mRNA: transcription of pNCT gene is regulated by external taurine concentration. Biochim Biophys Acta 1997, 1351(3):296-304

57. Han X, Budreau AM, Chesney RW: Molecular cloning and functional expression of an LLC-PK1 cell taurine transporter that is adaptively regulated by taurine. Adv Exp Med Biol 1998, 442:261-268.

58. Chesney RW, Friedman AL, Albright PW, Gusowski N: Fasting reverses the renal adaptation to altered dietary sulfur amino acid intake. Proc Soc Exp Biol Med 1982, 170(4):493-501.

59. Park T, Rogers QR, Morris JG, Chesney RW: Effect of dietary taurine on renal taurine transport by proximal tubule brush border membrane vesicles in the kitten. J Nutr 1989, 119(10):1452-1460.

60. Odobasic D, Kitching AR, Semple TJ, Holdsworth SR: Endogenous myeloperoxidase promotes neutrophil-mediated renal injury, but attenuates T cell immunity inducing crescentic glomerulonephritis. J Am Soc Nephrol 2007, 18(3):760-770.

61. Schieven GL, de Fex H, Stephenson L: Hypochlorous acid activates tyrosine phosphorylation signal pathways leading to calcium signaling and TNFalpha production. Antioxid Redox Signal 2002, 4(3):501-507.

62. Lian X, Yang L, Chen Q, Sheng A, Zhao J: Effects of taurine on platelet activating factor in rats with Masugi glomerulonephritis. Chinese $J$ Microcirc 2003, 7(3):151-153.

63. Li JZ, Sharma R, Dileepan KN, Savin VJ: Polymorphonuclear leukocytes increase glomerular albumin permeability via hypohalous acid. Kidney Int 1994, 46(4):1025-1030.

64. Trachtman H, Del Pizzo R, Futterweit S, Levine D, Rao PS, Valderrama E, Sturman JA: Taurine attenuates renal disease in chronic puromycin aminonucleoside nephropathy. Am J Physiol 1992, 262(1 Pt 2):F117-123.

65. United States Renal Data System. 2010 [http://www.usrds.org/2007/view/ 02_incid_prev].

66. Gossai D, Lau-Cam CA: The effects of taurine, taurine homologs and hypotaurine on cell and membrane antioxidative system alterations caused by type 2 diabetes in rat erythrocytes. Adv Exp Med Biol 2009, 643:359-368

67. Hansen SH: The role of taurine in diabetes and the development of diabetic complications. Diabetes Metab Res Rev 2001, 17(5):330-346.

68. Bergstrom J, Alvestrand A, Furst P, Lindholm B: Sulphur amino acids in plasma and muscle in patients with chronic renal failure: evidence for taurine depletion. J Intern Med 1989, 226(3):189-194.

69. Suliman ME, Barany P, Filho JC, Lindholm B, Bergstrom J: Accumulation of taurine in patients with renal failure. Nephrol Dial Transplant 2002, 17(3):528-529.

70. Erdem A, Gundogan NU, Usubutun A, Kilinc K, Erdem SR, Kara A, Bozkurt A: The protective effect of taurine against gentamicin-induced acute tubular necrosis in rats. Nephrol Dial Transplant 2000, 15(8):1175-1182.

71. Thadhani R, Pascual M, Bonventre JV: Acute renal failure. N Engl J Med 1996, 334(22):1448-1460.

72. Ries F, Klastersky J: Nephrotoxicity induced by cancer chemotherapy with special emphasis on cisplatin toxicity. Am J Kidney Dis 1986, 8(5):368-379.

73. Miyaji T, Kato A, Yasuda H, Fujigaki Y, Hishida A: Role of the increase in p21 in cisplatin-induced acute renal failure in rats. J Am Soc Nephrol 2001, 12(5):900-908.

74. Jiang $M$, Yi X, Hsu S, Wang CY, Dong Z: Role of $p 53$ in cisplatin-induced tubular cell apoptosis: dependence on p53 transcriptional activity. Am J Physiol Renal Physiol 2004, 287(6):F1140-1147.

75. Han X, Patters AB, Chesney RW: Transcriptional repression of taurine transporter gene (TauT) by p53 in renal cells. J Biol Chem 2002, 277(42):39266-39273.
76. Leibbrandt ME, Wolfgang GH, Metz AL, Ozobia AA, Haskins JR: Critical subcellular targets of cisplatin and related platinum analogs in rat renal proximal tubule cells. Kidney Int 1995, 48(3):761-770.

77. Matsell DG, Bennett T, Han X, Budreau AM, Chesney RW: Regulation of the taurine transporter gene in the $\mathrm{S} 3$ segment of the proximal tubule. Kidney Int 1997, 52(3):748-754.

78. Han X, Chesney RW: Mechanism of TauT in protecting against cisplatininduced kidney injury (AKI). Adv Exp Med Biol 2009, 643:105-112.

doi:10.1186/1423-0127-17-S1-S4

Cite this article as: Chesney et al:: Taurine and the renal system. Journal of Biomedical Science 2010 17(Suppl 1):S4.

\section{Submit your next manuscript to BioMed Central and take full advantage of:}

- Convenient online submission

- Thorough peer review

- No space constraints or color figure charges

- Immediate publication on acceptance

- Inclusion in PubMed, CAS, Scopus and Google Scholar

- Research which is freely available for redistribution 